\title{
PERBANDINGAN SEJARAH POSITIVISME HUKUM DI INDONESIA SEBAGAI PENENTU POLITIK HUKUM DIMASA YANG AKAN DATANG
}

\author{
Oleh : \\ Sigit Somadiyono*
}

\begin{abstract}
ABSTRAK
Terdapat tiga sistem hukum yang hidup dan berkembang serta berlaku di masyarakat Indonesia. ketiga sistem hukum tersebut adalah sistem hukum Islam, sistem hukum adat dan sistem hukum civil. Ketiga sistem itu saling "bersaing" untuk menjadi satu-satunya hukum yang berlaku di Indonesia. Walaupun begitu, ketiga sistem hukum tersebut sebenarnya bisa saling melengkapi dan bisa diharmonisasi. Tetapi Indonesia harus memiliki satu role model yang disepakati serta bisa menjadi panduan dalam merumuskan peraturan perundang-undangan yang berkeadilan. Tulisan ini menjelaskan bagaimana hukum adat dan hukum Islam tetap berlaku dan hidup dimasyarakat bisa mengisi kekosongan hukum dari sistem hukum civil. Metode penelitian yang digunakan adalah metode penelitian normatif dan menggunakan berbagai pendekatan yakni pendekatan undang-undang, perbandingan dan sejarah. Tulisan ini menyimpulkan bahwa walaupun pluralisme hukum yang berlaku di masyarakat dapat tumbuh dan saling melengkapi, tetapi pluarisme tersebut akan berdampak pada katidakpastian hukum serta arah perkembangan hukum yang tidak jelas ke depannya. Unifikasi dan kejelasan pengaturan terhadap ketiga sistem tersebut akan menjadi salah satu jawaban atas pluralisme hukum di Indonesia sehingga tercipta keadilan dan ketertiban di masyarakat.
\end{abstract}

Kata Kunci: Sejarah Positivisme, Indonesia, Hukum Islam, Hukum Adat

\section{A. Pendahuluan}

Sistem berasal dari bahasa Yunani yaitu systema, artinya adalah keseluruhan yang terdiri dari bermacam-macam bagian. Sistem hukum menurut Subekti adalah suatu susunan atau tatanan yang teratur, suatu keseluruhan yang terdiri atas bagian-bagian yang berkaitan satu sama lain, tersusun menurut suatu rencana atau pola, hasil dari suatu penulisan untuk mencapai suatu tujuan. Sistem hukum dapat diartikan sebagai kumpulan sikap yang telah mengakar kuat dan terbentuk dalam waktu yang lama sehingga berpengaruh terhadap pemberlakuan hukum di masyarakat. ${ }^{1}$

Perkembangan pemikiran terkait sistem hukum terus berkembang dan menimbulkan berbagi teori yang terus dikritisi dan dilaksanakan walupun belum terdapat kesepakatan tentang apakah teori ini murni heuristik, ilmiah dan mendasar atau apakah berguna secara teoritis dan deskriptif. Bahkan ketika konsep tentang sistem hukum digunakan meskipun

\footnotetext{
* Pengajar Program Magister Ilmu Hukum UNBARI

${ }^{1}$ Inu Kencana Syafii, Sistem Administrasi Negara Republik Indonesia (SANRI), Jakarta : Bumi Aksara, 2003, hal. 2.
} 
belum ada kriteria klasifikasinya. Demikian juga belum ada kesepakatan berkenaan dengan pengelompokan berbagai sistem hukum. ${ }^{2}$

Pengertian sistem hukum dalam arti luas diartikan sebagai filsafat yuristik dan teknik yang sama yang digunakan oleh sejumlah negara yang secara umum memiliki kesamaan sistem hukum. Sistem hukum dalam arti luas ini menggambarkan sebuah keluarga hukum induk, seperti keluarga Islamic Law, Civil Law, Common Law, Adat Law dan Socialist Law. ${ }^{3}$

Sejarah perkembangan sistem hukum di Indonesia tidak terlepas dari zaman prasejarah dan sejarah kerajaan-kerajaan sebelum masuknya petualang dan/atau pedagang dari Arab dan Eropa ke nusantara. Kedaulatan kepala suku dan raja dalam menentukan hukum yang berlaku diwilayahnya membuat nusantara (baca: Indonesia) memiliki hukum yang berbeda-beda, khususnya pada hukum adat. Kemudian hukum tersebut diperkaya dengan menyebarnya agama Islam di nusantara yang memiliki corak hukum berbasis agama.

Perkembangan sistem hukum di Indonesia saat ini merupakan imbas dari pemikiran yang beragam untuk menuju sistem hukum yang mendukung semangat bangsa. Hukum Adat, Hukum Islam dan Hukum Eropa (hukum Kontinental) masih berlaku di Indonesia tetapi sudah memiliki batasan yang jelas tentang keberlakuannya. Semua tatanan hukum sudah diatur sedemikian rupa sehingga walaupun terjadi pertentangan antar sistem hukum, maka sudah ada penyelesaian yang disepakati. ${ }^{4}$

Sebelum hadirnya pemerintahan Kolonial Belanda di nusantara, masyarakat pribumi di samping telah mempunyai ciri khas adat tersendiri juga telah bersinggungan dengan peradaban luar, salah satunya adalah ajaran-ajaran Hindu-Budha dan Islam. Oleh karenanya, aturan hukum yang lebih dikenal pada waktu itu adalah hukum Islam yang memang telah menyatu dengan budaya adat setempat. Pada dasarnya, kedua budaya ini (Islam dan adat) dapat berjalan seiring-seirama dan menjadi aturan yang menjadi norma-norma yang hidup pada masyarakat pribumi di nusantara. Adanya "perkawinan" budaya ini, tidak lain karena ajaran Islam mengikat pada pribadi setiap muslim dan selalu menghormati adat setempat di manapun ia singgah. Syarat berlakunya hukum lain selain hukum Islam bagi para penganunya

\footnotetext{
${ }^{2}$ Peter de Cruz, Perbandingan Sistem Hukum Common Law, Civil Law and Socialist Law, Bandung : Nusa Media, 2010, hal. 49.

${ }^{3}$ Zaka Firman Aditya \& Rizkisyabana Yulistyaputri, Romantisme Sistem Hukum di Indonesia : Kajian atas Kontribusi Hukum Adat dan Hukum Islam terhadap Pembangunan Hukum di Indonesia, Jurnal Rechts Vinding, Volume 8, Nomor 1, April 2019.

${ }^{4}$ Penyelesaian tersebut hanya bersifat umum, yaitu hukum adat khusus berlaku pada wilayah tertentu, hukum Islam berlaku untuk orang-orang yang beragama Islam dan hukum civil berlaku secara umum di Indonesia. Bila ada pertentangan keberlakuannya antar sistem hukum, maka hukum nasional menjadi sumber tertinggi penggunaan hukum dengan perangkat negara sebagai esekutornya.
} 
adalah harus sejalan dan tidak bertenangan dengan ajarannya. Artinya ajaran Islam tidak bersikap keras dan "main bunuh" terhadap budaya lain.

Keharmonisan budaya adat dan Islam ini menjadi terganggu dengan adanya "pendekatan konflik" pemerintah Hindia Belanda terhadap kedua ajaran ini. Pemerintah Belanda sengaja membenturkan budaya adat dengan ajaran Islam, yang pada dasarnya menyatu bagai sifat dan zat. Dalam mata Belanda hukum adat vis a vis hukum Islam. Lebih jauh, pemerintah Belanda lebih mendukung pemberlakuan hukum adat daripada hukum Islam. Namun demikian, Belanda bukan berarti "membela" hukum adat demi kemaslahatn penduduk pribumi, melainkan hanya sebagai alat politisasi agar melanggengkan kekuasaannya di bumi jajahan. ${ }^{5}$

Strategi pemerintah kolonian Belanda dengan menggunakan hukum sebagai alat pemecah belah penduduk nusantara adalah dengan memberlakukan Pasal 131 Indische Staatsregeling. Strategi ini cukup jitu dan dampaknya masih terasa hingga kini dimana penduduk Indonesia terbelah-belah secara yuridis dalam tiga golongan yaitu golongan Eropa, golongan Timur Asing dan golongan Bumi Putra.

Setelah kemerdekaan Indonesia diploklamirkan pada tanggal 17 Agustus 1945, kondisi sistem hukum Indonesia yang pluralistik masih terus berlangsung dengan berlakunya Pasal II Aturan Peralihan UUD 1945. Pasal tersebut mengatur tentang masih berlakunya hukum kolonial sepanjang belum adanya hukum yang baru. Aturan tersebut dianggap wajar pada saat tersebut mengingat Indonesia masih belum bisa membuat aturan hukum dikarenakan situasi dan kondisi bangsa yangs sedang berjuang. Hingga kini, pemberlakuan Pasal II Aturan Peralihan UUD 1945 tersebut masih ada dan terus berlaku dikarenakan masih banyak peraturan peninggalan kolonial yang belum dapat tergantikan dengan berbagai faktor dan alasan.

Pluralisme dan kemajemukan hukum pada sejarah Indonesia di satu sisi "memperkaya" budaya hukum tetapi juga mengakibatkan beberapa hal sebagai berikut: 6

1. Berlakunya hukum yang plural dan majemuk di Indonesia menyebabkan tidak adanya kepastian hukum;

2. Persepsi masyarakat tentang hukum Indonesia yang plural dan majemuk akan membahayakan kesatuan serta persatuan di Indonesia.

${ }^{5}$ Subekti, Pokok-Pokok Hukum Perdata, Jakarta: Intermasa, 1985, hal. 10-14. Lihat juga Moh. Mahfud MD, Politik Hukum di Indonesia, Jakarta: Pustaka LP3ES Indonesia, 2001, hal. 9

${ }^{6}$ Anak Agung Putu Wiwik Sugiantari, Perkembangan Hukum Indonesia dalam Menciptakan Univikasi dan Kodifikasi Hukum, Jurnal Advokasi Vol. 5 No. 2 September 2015, hal. 110. 
3. Banyaknya kepentingan akibat dari sistem hukum yang majemuk dan plural mengakibatkan konflik sulit diselesaikan.

4. Adanya pendapat putra daerah dan pendatang akibat munculnya otonomi daerah berakibat timbulnya perpecahan;

5. Hukum yang berbeda disetiap daerah akan menyulitkan terciptanya sistem hukum yang berjiwa kebangsaan

Negara Indonesia telah menegaskan sebagai negara hukum sebagaimana diatur dalam Undang-Undang Dasar 1945 pada Pasal 1 Ayat (3). Indonesia menganut tiga sistem hukum secara bersama-sama yang saling berkembang yaitu hukum adat, hukum Islam dan hukum Kontinental. Sistem hukum Kontinental memiliki ciri hukum tertulis masuk dan berkembang di nusantara selama masa kolonial Belanda dan tetap bertahan hingga sekarang meskipun masa kolonial telah berakhis lebih dari 72 tahun yang lalu. Hingga saat ini, pengaruh sistem hukum Kontinental khusunya hukum Belanda masih eksis dan berlaku di Indonesia. $^{7}$

\section{B. Metode Penulisan}

Metode penelitian yang digunakan adalah metode normatif yang bersifat prespektif. Pada umumnya pendekatan penelitian menurut Peter Mahmud Marzuki adalah pendekatan melalui undang-undang, konseptual, kasus, perbandingan dan sejarah. Pada tulisan ini, penulis melakukan pendekatan undang-undang, pendekatan perbandingan dan sejarah.Pendekatan undang-undang dilakukan dengan menelaah semua peraturan perundangundangan yang terkait dengan isu yang sedang dikaji yaitu peraturan perundang-undangan yang terkait dengan hukum Adat, hukum Islam dan hukum Kolonial. Pendekatan sejarah berkaitan dengan sejarah hukum dari pemberlakuan hukum adat, hukum Islam dan hukum kolonial di Indonesia. Sedangkan pendekatan perbandingan dilakukan dengan cara membandingkan penerapan hukum Adat, hukum Islam dan hukum Kolonial di Indonesi.

\section{Pembahasan}

\section{Perbandingan Sejarah Positivisme Hukum di Indonesia}

Perkembangan hukum di Indonesia pada awalnya dimulai pada zaman prasejarah dimana hukum berasal dari kekuatan penguasa kelompok. Kemudian berkembang menjadi kekuatan penguasa daerah dan terus meluas menjadi kerajaan. Sifat hukum pada zaman

\footnotetext{
${ }^{7}$ Zaka Firman Aditya \& Rizkisyabana Yulistyaputri, Op. Cit.
} 
prasejarah adalah bersifat tradisional dan terbuka. Sifat tradisional hukum adat adalah melanjutkan tradisi leluhur dan cenderung mempertahankan nilai serta pola yang terbentuk dalam kebiasaan dan lingkungan masyarakatnya. Sedangkan sifat terbuka dari hukum adat adalah mampi mengikuti dan menerima perkembangan yang terjadi dilingkungan masyarakatnya. ${ }^{8}$

Perkembangan hukum adat semakin dinamis dengan masuknya pengaruh agama Hindu dan Budha ke Nusantara. Terbentuknya kerajaan Kutai, kerajaan Sriwijaya dan kerajaan-kerajaan lain yang bercorak Hindu-Budha mempengaruhi hukum adat yang berlaku di wilayah kerajaan tersebut. ${ }^{9}$ Tidak hanya sampai disitu, hukum adat kembali menyelaraskan diri dengan masuknya hukum Islam di Nusantara pada sekitar abad ke 12. ${ }^{10}$

Sebagai hukum yang hidup dan berkembang, hukum adat mengalami perubahan dan penggeseran sebagai imbas dari perubahan yang terjadi dimasyarakat. Akibatnya ada sebagian hukum adat yang dapat bertahan dan ada sebagian lain yang menghilang. Hukum adat yang masih bertahan adalah hukum yang sifat aturannya adalah sensitif, terkait nilai budaya dan keyakinan (hukum waris dan hukum keluarga). Sedangkan hukum adat yang telah melebur dan walaupun ada tidak mempunyai kekuatan keberlakuannya adalah hukum adat terkait ketentuan pidana dan ketentuan ekonomi.

Masuknya Islam ke Nusantara dengan membawa ajaran berintikan ibadah, juga membawa ajaran-ajaran hukum yang wajib ditaati oleh penganut agama Islam. Sifat hukum Adat yang terbuka dan dinamis serta hukum Islam yang semi terbuka (Selama tidak bertentangan dengan Al-Qur'an dan Hadist) menjadikan perpaduan norma yang saling melengkapi. Perpaduan norma inilah yang kemudian diterapkan dan dijalankan sehingga melahirkan adat kebiasan dan selajutnya berubah menjadi hukum adat.

Permasalahan yang muncul dan terjadi dari percampuran antar hukum Islam dan hukum Adat adalah dalam tingkat penerapan dan pengaturannya. Tidak jarang penerapan dan

\footnotetext{
${ }^{8}$ Lihat : Ahmad Ubbe, Perkembangan Hukum Adat di Provinsi Sulawesi Selatan, Laporan Akhir Penelitian Hukum, Jakarta: Badan Pembin Hukum Nasional Departemen Hukum dan Hak Asasi Manusia, 2005, hal. 37. Lihat juga Rikardo dkk, Pluralisme Hukum Sebuah Pendekatan Interdisiplin, Jakarta: Huma, 2005, hal 21

${ }^{9}$ Banyak Teori dan opini yang diberikan para ahli sejarah tentang masuknya agama Hindu-Budha ke Nusantara antarai lain : (1) Teori Brahmana yang menurut J.C. Van Leur masuknya agama Hindu-Budha karena dibawa oleh golongan Brahmana; (2) Teori Kesatria yang menurut C.C. Berg masuk ke nusantara karena dibawa oleh golongan kasta Ksatria yang kalah perang kemudian melarikan diri mencari daerah baru hingga ke nusantara; (3) Teori Waisya yang dikemukakan oleh N.J. Krom mengenai masuknya agama Hindu-Budha ke Nusantara melalui hubungan dagang; (4) Teori Arus Balik oleh F.D.K Bosch yang menyatakan banyak orang Nusantara yang sengaja datang ke India untuk belajar agama Hindu-Budha kemudian kembali ke Nusantara untuk menyebarkannya.

${ }^{10}$ Azyumzrdi Azra, Jaringn Ulama Timur Tengah dan Nusantara, Jakarta: Kencana, 2007, hal. 2.
} 
pengaturan hukum Islam dianggap bagian dari hukum adat dan begitu juga sebaliknya hukum adat dianggap sebagai hukum Islam. Hal ini berimbas pada sanksi yang akan diberikan kepada pelanggar aturan tersebut, apakah menggunakan sanksi adat atau menggunakan sanksi agama yang keduanya tidak mempunyai legitimasi yang jelas dan kuat untuk diterapkan.

Salah satu contoh dari pencampuran yang sulit dipisahkan antara hukum adat dan hukum Islam adalah dalam bidang pernikahan. Penggunaan ijab qabul dalam perkawinan adalah salah satu syarat sahnya perkawinan dalam hukum Islam, tetapi adat istiadat masuk dalam tata cara perayaan pernikahan kedua mempelai. Tidak jarang terjadi percampuran yang sulit menjadi pembeda apakah ini hukum Islam atau hukum Adat.

Pada abad ke 15, banyak pedagang dan petualang dari Eropa berdatangan ke wilayah-wilayah Nusantara. Tujuan mereka adalah menemukan daerah dan wilayah pedagangan baru. Rempah-rempah dan kekayaan bumi lainnya yang ada di Nusantara menjadikan daya tarik pedagang dan petualang dari Eropa. Perkembangan selanjutnya, bangsa Eropa memperluas bentuk penguasaannya dari hubungan perdagangan yang setara dan sama menjadi bentuk penguasaan dan monopoli serta penjajahan terhadap wilayah-wilayah nusantara. Banyak kerajaan di nusantaa yang ada tapi tidak memiliki kedaulatan lagi, atau ada sebagian kerajaan yang berakhir tragis ditangan bangsa Eropa.

Hilangnya kedaulatan atau musnahnya kerajaan di Nusantara mengakibatkan masuknya pengaruh hukum dari bangsa Eropa. Hukum adat yang awalnya hanya bersinggungan dengan hukum Islam, kembali melebur masuk ke hukum kolonial khususnya hukum Belanda yang menggunskan sistem hukum Kontinental. Kedudukannya hukum Adat dan hukum Islam yang pada awalnya sama dengan hukum Eropa, berubah menjadi timpang seiring tidak adanya lagi kedaulatan para raja nusantara.

Puncaknya pada akhir abad ke 18 muncul sistem hukum baru di Nusantara dalam dua bentuk hukum yaitu hukum tertulis (hukum yang tertuang dalan perundang-undangan) dan hukum yang tidak tertulis (hukum adat, hukum kebiasaan). Hukum tertulis adalah hukum yang dibuat dan ciptakan berdasarkan hukum Eropa dan berlaku umum di seluruh nusantara. Sedangkah hukum Islam dan Hukum Adat hanya berlaku bagi golongan Bumiputra dalam agama dan wilayah tertentu saja.

Atas pemberlakuan tersebut menimbulkan gejolak yang berujung pada perlawanan masyarakat hukum adat ataupun masyarakat hukum Islam dinusantara terhadap kaum kolonial yang berasal dari Eropa khususnya yang berasal dari Belanda. Kemudian kebijakan pemberlakuan hukum Islam dan Hukum Adat diperlunak setelah munculnya teori reception in 
complex yang dicetus oleh Cristian van Berg yang kemudian teori ini dibantah oleh teori receptie oleh Snouck Hurgronye.

Pasca kemerdekaan, hukum Adat, hukum Islam dan hukum Kontinental mengalami perkembangan dan proses pelembagaan yang berlainan. Hukum Kontinental relatif tidak mengalami perubahan. Hukum Adat berkembang melalui yurisprudensi yang menjadi pegangan para hakim untuk menemukan keadilan yang hidup dimasyarakat. ${ }^{11}$ Sedangkan hukum Islam masuk dan lebur dalam berbagai hukum nasional yang baru terkait dengan pengaturan-pengaturan yang bersifat ibadah dan muamalah bagi orang-orang muslim.

Terjadi kejanggalan hingga kini dalam pemberlakuan ketiga sistem hukum tersebut di Indonesia, walau UUD 1945 dan amandemennya sudah tidak mengenal lagi penggolongan golongan penduduk tetapi tetap terjadi pembeda dalam penerapan hukumnya. Salah satu contohnya adalah apabila ada masyarakat Adat yang yang beragama Islam masih dapat "memaksakan" pilihannya apakah tunduk pada hukum Adat, hukum Islam ataupun hukum nasional. Hal tersebut mengakibatkan tidak adanya kepastian hukum bagi para pihak khususnya pihak yang dirugikan.

Arah perkembangan ketiga sistem hukum tersebut harus diatur dalam aturan yang jelas dan konkrit. Ketidakadaan aturan yang jelas terkait perkembangan ketiga sistem hukum tersebut akan semakin memperbesar jurang pemisah dari ketiga sistem hukum tersebut. Dampak utama dari besarnya jurang pemisah dari pemberlakuan ketiga sistem hukum tersebut adalah tidak adanya kepastian hukum. Pendekatan sejarah dari dampak pemisahan yang tetap pada pluralisme atau penyatuan ketiga sistem hukum berupa unifikasi hukum di Indonesia akan menjadi panduan terhadap arah perkembangan hukum nasional.

Hukum Adat dan hukum Islam berdasarkan sejarah yang panjang telah dapat melebur dalam kehidupan masyarakat Indonesia. Prinsip hukum Kontinental yang bersifat tertulis dapat dipadukan padankan dengan hukum Islam dan hukum Adat. Selama hukum nasional yang diciptakan tidak bertentangan dengan kedua sistem hukum lainnya maka dapat menjadi jembatan untuk terciptanya kepastian hukum. Hal itu sejalan dengan perkembangan sistem hukum suatu bangsa yang tidak terikat pada satu induk pengelompokan sistem hukum. Perkembangan sistem hukum di dunia akan terus berkembang seiring munculnya teori-teori dan perkembangan pengetahuan hukum.

\footnotetext{
${ }^{11}$ Sigit Somadiyono, Peran Kantor Wilayah Provinsi Jambi dalam Penyelesaian Sengketa Pertanahan melalui Mekanisme Mediasi, Wajah Hukum, Vol 1, No 1, Oktober 2017.
} 
Pendekatan sejarah dan pendekatan perbandingan akan menjadi kunci untuk memunculkan sistem hukum yang baru dan berkeadilan. Pendekatan sejarah akan mengajarkan tentang dampak yang dihasilkan dari unifikasi ataupun pembiaran pluralisme hukum. Sedangkan pendekatan perbandingan akan memberikan informasi terhadap hukum yang berlaku ditempat lain sehingga bisa menjadi acuan dalam memilih unifikasi hukum ataupun jalanya pluralisme hukum. Pada dasarnya sistem hukum yang dibentuk dan terbentuk bertujuan untuk menterjemahkan keadilan dalam kehidupan berbangsa dan bernegara. Pilihan unifikasi sistem hukum ataupun tetap pada pluralisme sistem hukum merupakan dua pilihan yang akan tetap menjadi bahan perdebatan tentang nilai-nilai keadilan.

\section{Politik Hukum Penciptaan Univikasi Hukum di Indonesia}

Indonesia merupakan negara yang memiliki keanekaragaman agama, budaya dan suku tentunya bukan hal yang mudah untuk melakukan univikasi hukum nasional. Pemerintahan zaman kerajaan, Hindia Belanda dan pemerintah Indonesia setelah merdeka pun terus melakukan unifikasi hukum, namun menemukan kegagalan. Sampai dengan saat ini Indonesia menggunakan sistem hukum nasional yang harus berdampingan dengan sistem hukum adat dan sistem hukum Islam.

Pluralisme hukum yang ada di Indonesia, meskipun sebagai hukum tidak tertulis justru mampu menjadi pemersatu, dan menjadi solusi bahkan menciptakan ketentraman dalam pergaulan hidup masyarakat. Pluralisme hukum di Indonesia secara dinamis mengikuti perkembangan masyarakatnya dengan tetap bertumpu pada karakteristik masyarakat adat dan pola pikir participerend coschmish menarik minat para pakar dari penjuru dunia untuk dijadikan objek penelitian.

Berbicara tentang relasi antara hukum dan politik adalah berbicara bagaimana hukum bekerja dalam sebuah situasi politik tertentu. Dalam hal ini yang dimaksud adalah hukum sebagai perwujudan dari nilai-nilai yang berkembang dan nilai-nilai yang dimaksud adalah keadilan. Dengan demikian idealnya hukum dibuat dengan mempertimbangkan adanya kepentingan untuk mewujudkan nilai-nilai keadilan tersebut. Dengan ciri-ciri mengandung perintah dan larangan, menuntut kepatuhan dan adanya sanksi, maka hukum yang berjalan akan menciptakan ketertiban dan keadilan di masyarakat. ${ }^{12}$

${ }^{12}$ Merdi Hajiji, Relasi Hukum dan Politik dalam Sistem Hukum Indonesia, Jurnal Rechts Vinding, Volume 2, Nomor 3, Desember 2013. 
Arah yang jelas dari politik hukum yang akan, sedang dan telah diberlakukan di Indonesia sangat penting, karena hal tersebut akan menjadi sebagai pedoman dasar dalam proses penentuan nilai-nilai, penetapan, pembentukan dan pembangunan hukum di Indonesia. Artinya, baik secara normatif maupun praktisi-fungsional, penyelenggara negara harus menjadikan politik hukum sebagai acuan pertama dan utama dalam proses-proses di atas. Menurut Daniel S. Lev, yang paling menentukan dalam pembentukan hukum adalah konsepsi dan kekuasaan politik, yaitu bahwa hukum sedikit banyak selalu merupakan alat politik, dan bahwa tempat hukum dalam negara, tergantung pada keseimbangan politik, definisi kekuasaan, evolusi idiologi politik, ekonomi, sosial dan seterusnya. ${ }^{13}$

Pembahasan tentang univikasi dan pluralisme hukum memang merupakan perdebatan yang sangat panjang. Hal ini dikarenakan masing-masing mempunyai dasar yang cukup kuat untuk mempertahankan eksistensinya. Unifikasi hukum meniscayakan hukum yang bisa berkembang menyesuaian kondisi masyarakat di mana dia hidup.

Di Indonesia secara historis unifikasi hukum sendiri sebenarnya baru seumur jagung, hanya saja perkembangan terkini lebih mengarah pada unifikasi sejalan dengan terbentuknya negara. Sementara pluralisme hukum sudah ada jauh sebelum terbentuknya negara, sehingga ketika datang budaya unifikasi, pluralisme hukum terancam keberadaannya. Keberadaan hukum-hukum lain yang sudah lama berada di Indonesia seperti hukum Islam dan hukumhukum adat masyarakat Indonesia yang berbeda-bedapun terancam juga.

Seiring dengan adanya budaya unifikasi dalam hukum negara Indonesia maka ada banyak golongan yang memperjuangkan produk hukum menjadi hukum unifikasi dan berlaku untuk seluruh masyarakat di Indonesia. Di antara produk unifikasi hukum adalah hukum perkawinan. Di sisi lain seiring dengan adanya budaya unifikasi, hukum-hukum adat masih mengakar dan mempunyai pengaruh kuat di dalam masyarakat. Bahkan di beberapa di daerah di Indonesia hukum Islam telah hidup dan menjadi dasar dari hukum adat.

Menurut Erman pluralitas merupakan ciri khas Indonesia sejak dahulu jauh sebelum merdeka. Pada abad 19 pemerintah Hindia Belanda memutuskan untuk memberlakukan hukum perdata Belanda untuk Indonesia. Van Vollenhoven sebagai orang Belanda yang menentang pemberlakuan hukum tersebut. Menurut Van Vollenhoven geen juristenrecht voor de Inlanders (tidak akan ada hukum yang cuma dimengerti pakar-pakar hukum bisa diterapkan untuk rakyat pribumi yang dalam kehidupan sehari-hari telah memiliki hukumnya

${ }^{13}$ Daniel S. Lev, Hukum dan Politik di Indoensia Kesinambungan dan Peru bahan, Jakarta : LP3ES, 1990, hal. xi. 
sendiri). Lebih pantaslah kiranya apabila hukum rakyat (yang oleh van Volenhoven dan Snouck Hurgronje pendahulunya disebut "hukum adat") direkam dan dipelajari dulu untuk kemudian dikodifikasikan untuk dipedomani tindakan-tindakan hukum rakyat itu sendiri.

Penerus van Vollenhoven, ialah ter Haar dan para muridnya yang belajar di Sekolah Tinggi Hukum di Jakarta (yang pada waktu itu bernama rechtshogeschool te Batavia) mulai bekerja di lapangan untuk mencatat kaidah-kaidah sosial (adat) komunitas-komunitas dengan sanksi-sanksi. Hasil-hasil kerja di lapangan itu dicatat dan diterbitkan dalam buku-buku dan majalah-majalah hukum, dan acap kali (walaupun tidak diresmikan sebagai kodifikasi) dipakai sebagai rujukan oleh hakim-hakim pengadilan negeri yang mengadili perkara-perkara antara orang-orang pribumi. Berkat perjuangan van Vollenhoven dan ter Haar serta para penerusnya itu, pada zaman Hindia Belanda itu hukum negara yang diterapkan (oleh badanbadan yudisial pemerintah kolonial) yang menjad tidak - atau tidak banyak - menyimpang dari hukum yang hidup ditengah-tengah masyarakat. ${ }^{14}$

Namun usaha itu justru tidak diteruskan oleh bangsa Indonesia setelah terbentuknya negara Kesatuan Republik Indonesia. Perkembangan hukum nasional di Indonesia berlangsung seiring dengan perkembangan kekuasaan negara-negara bangsa. Hukum nasional itu pada hakekatnya adalah hukum yang pengesahan pembentukan dan pelaksanaannya bersumber dari kekuasaan dan kewibawaan negara. Tatkala kehidupan berkembang ke dalam skala-skala yang lebih luas, dari lingkar-lingkar kehidupan komunitas lokal (old societies) ke lingkar-lingkar besar yang bersifat translokal pada tataran kehidupan berbangsa yang diorganisasi sebagai suatu komunitas politik yang disebut negara bangsa yang modern (new nation state), kebutuhan akan suatu sistem hukum yang satu dan pasti amatlah niscaya.

Adanya unifikasi terhadap kondisi majemuk yang ada di Indonesia menyebabkan banyak permasalahan ketika hukum dalam kelompok masyarakat diterapkan dalam transaksi tertentu atau saat terjadi konflik, sehingga ada kebingungan hukum yang manakah yang berlaku untuk individu tertentu dan bagaimana seseorang dapat menentukan hukum mana yang berlaku padanya.

Sementara itu, dalam tulisannya yang berjudul The Commission on Folk Law and Legal Pluralism Anne Griffith menjelaskan bahwa saat ini kita hidup tidak dengan satu hukum tetapi dengan berbagai hukum sehingga pemahaman mengenai pluralisme hukum perlu diberikan kepada pengambil kebijakan, ahli hukum, antopolog, sosiolog dan ilmuwan

14 Lihat : Soetandyo Wignjosoebroto, Masalah Pluralisme dalam Sistem Hukum Nasionai, https://soetandyo.wordpress.com/2010/08/19/masalah-pluralisme-dalam-sistem-hukum-nasional/ diunduh pada tanggal 31 Mei 2020. 
sosial lainnya. Pemahaman akan pluralisme hukum akan menciptakan hukum dalam format yang berbeda dan mengakomodir perbedaan disetiap sistem hukum. Hal itu akan menjadikan pemberlakuan hukum dapat diterima oleh masyarakat secara sukarela dan tanpa adanya paksaan. ${ }^{15}$

Perkembangan pluralisme hukum dalam gerakan perubahan hukum muncul melalui advokasi-advokasi terhadap masyarakat adat. Dalam konteks ini, pluralisme hukum dipakai untuk membela tanah-tanah masyarakat yang diambil paksa oleh negara atau pelaku swasta. Singkatnya, konsep pluralisme hukum dipakai untuk mengangkat. kembali keberadaan hukum adat, dalam upaya untuk melindungi sumber daya alam yang dimiliki masyarakat adat dari perampasan-perampasan yang diabsahkan hukum negara.

Gerakan masyarakat yang memilih pluralisme hukum juga mencoba merambah ranah penyelesaian sengketa, yaitu dengan mendorong terciptanya pelembagaan terhadap lembagalembaga penyelesaian hukum adat (peradilan adat). Hal ini dianggap sebagai salah satu jawaban terhadap situasi lembaga penyelesaian sengketa negara (pengadilan) yang belum bisa menggali nilai-nilai keadilan di masyarakat. Tujuan dari gerakan ini adalah untuk memberik tawaran untuk membiarkan masyarakat menyelesaikan persoalannya sendiri melalui peradilan adat tanpa melalui melibatkan pengadilan. ${ }^{16}$

Gerakan perubahan hukum di Indonesia dengan menggunakan pluralisme hukum sebagai pijakan, telah melangkah cukup jauh. Salah satunya adalah dengan diakuinya hak-hak masyarakat adat, termasuk hukumnya dalam konstitusi. Berikut di antara peraturan yang mengabsahkan berlakunya hukum adat : Peraturan Mendagri No.3 tahun 1997 tentang Pemberdayaan dan Pelestarian Serta Pengembangan Adat Istiadat, Kebiasaan-kebiasaan Masyarakat, dan Lembaga Adat di Daerah. Undang-undang Dasar 1945 Amandemen, hukum adat diakui sebagaimana dinyatakan dalam Pasal 18B ayat (2) yang menyatakan: Negara mengakui dan menghormati kesatuan-kesatuan masyarakat hukum adat beserta hak-hak tradisionalnya sepanjang masih hidup dan sesuai dengan perkembangan masyarakat dan prinsip negara Kesatuan Republik Indonesia, yang diatur dalam undang-undang.

Hasil dari semua itu saat ini ada tiga produk hukum yang hidup dalam masyarakat Indonesia yaitu hukum negara, hukum Agama, dan hukum adat, karena ketiganya sudah

\footnotetext{
${ }^{15}$ https://www.hukumonline.com/berita/baca/hol15089/pluralisme-hukumharus-\%20diakui\%20diakses di unduh pada tanggal 30 Mei 2020

${ }^{16} \mathrm{http} / / /$ grupsyariah.blogspot.com/2012/06/pluralisme-hukum-di-indonesia di unduh pada tanggal 30 Mei 2020.
} 
diakui secara kontitusional. Artinya masyarakat Indonesia diberi kebebasan untuk menggunakan di antara tiga produk hukum itu.

Kerumitan yang berpangkal dari konflik keberlakukan sistem hukum antara hukum Kontinental, hukum Islam dan hukum Adat sudah seharusnya dicarikan solusi penyelesaiannya. Ada dua tawaran konsep penyelesaianya yaitu:

1. Membiarkan sistem hukum tetap pada keberagaman dan manakala timbul konflik sistem hukum kemudian diserahkan kepada pengadilan;

2. Melakukan unifikasi sistem hukum dengan membuat peraturan perundangundangan baru pada semua bidang yang bersifat nasional.

Dalam rangka mewujudkan kebersatuan bangsa, salah satunya hanya dapat dicapai melalui unifikasi hukum. Ide untuk mempertahankan pluralisme hukum tentu saja tidak sejalan dengan cita-cita "hukum yang sama untuk semua orang". Jika pluralitas hukum dipertahankan, tentu saja akan terjadi distorsi terhadap cita-cita persamaan hukum tersebut. Pada aras yang lebih mendasar, tidak ada landasan konstitusionalnya untuk membuat hukum yang berbeda-beda yang diterapkan bagi golongan-golongan penduduk yang berbeda pula. Jika ditengok lebih dalam maka konstitusi Indonesia tidak mengenal penggolonganpenggolongan penduduk.

Argumentasi untuk tetap mempertahankan perbedaan sistem hukum di Indonesia dalam keadaan beranekaragam ternyata lebih banyak mengandung konsekuensi negatif, sebab dengan tetap membiarkan keadaan ini terus berlangsung, jelas bertentangan dnegan cita-cita bangsa yang berkeinginan untuk memiliki hukum nasional yang terunifikasi dan terkodifikasi yang merupakan produk bangsa sendiri. Dengan pembiaran tersebut, hal ini juga berarti melestarikan terjadinya konflik hukum antara ketiga sistem hukum yang sudah terjadi sejak masa penjajahan Beland dan yang hingga kini terus berlangsung. ${ }^{17}$

\section{Penutup}

Pluralisme ketiga sistem hukum di Indonesia masih menjadi penyebab ketidakpastian hukum. Pilihan hukum atas ketiga sistem tersebut pada realitanya menjadikan subjek hukum lebih memilih hukum yang menguntungkan bagi dirinya. Ketidaksamaan persepsi tentang keberagaman sistem hukum berimbas pada penegakkan hukum pada wilayah yang masih

${ }^{17}$ Busthanul Arifin, Pelembagaan Hukum Islam di Indonesia, Akar Sejarah, Himbauan dan Prospeknya, Jakarta: Gema Insani Press, 1996, hal. 32. 
kental hukum adatnya tetapi terkait dengan subjek hukum yang beragama Islam serta jauh dari perangkat hukum nasional.

Perkembangan pluralisme hukum di Indonesia seperti tidak memiliki arah yang jelas. Ketiga sistem hukum berjalan pada relnya masing-masing. Sistem hukum nasional yang satu dan berlaku untuk semuanya akan menjadi terkoyak apabila tidak ada rood map yang jelas dari para pembuat hukum. Pembatasan perkembangan juga bukan menjadi pilihan yang baik tapi tidak ada salahnya memberikan panduan perkembangan ketigas sistem hukum sehingga terbentuklah hukum nasional yang kuat dan berlaku mutlak bagi seluruh rakyat Indonesia.

Ditinjau dari teori pluralisme hukum maka menurut hemat penulis beberapa sistem hukum yang ada dan nyata dalam masyarakat tidaklah perlu dipertentangkan atau bahkan saling melemahkan, selama sistem-sistem hukum itu mempunyai tujuan yang sama secara prinsipil. Ada beberapa hal konkret yang bisa dipertimbangkan dalam menengahi permasalahan dalam negara yang mempunyai sistem hukum yang plural seperti di Indonesia.

Sedangkan dari teori univikasi hukum menyebabkan adanya kepastian hukum yang menjadi dasar pemberlakuan hukum yang berkeadilan. Kejelasan akan hukum yang berlaku membuat hukum dapat ditegakkan dengan baik dan sempurna. Namun dalam melakukan univikasi hukum juga perlu kehati-hatian agar hukum yang diciptakan tidak mengakibatkan matinya hukum yang ada. Risiko univikasi hukum yang utama adalah adanya penolakan pemberlakuan hukum tersebut di masyarakat sehingga daya pemberlakuannya menjadi berkurang ataupun tidak punya daya pemberlakuannya sama sekali.

\section{G. Daftar Pustaka}

Ahmad Ubbe, Perkembangan Hukum Adat di Provinsi Sulawesi Selatan, Laporan Akhir Penelitian Hukum, Badan Pembinaan Hukum Nasional Departemen Hukum dan Hak Asasi Manusia, Jakarta, 2005.

Anak Agung Putu Wiwik Sugiantari, Perkembangan Hukum Indonesia dalam Menciptakan Univikasi dan Kodifikasi Hukum, Jurnal Advokasi, Vol. 5 No. 2 September 2015.

Azyumzrdi Azra, Jaringan Ulama Timur Tengah dan Nusantara, Kencana, Jakarta, 2007.

Busthanul Arifin, Pelembagaan Hukum Islam di Indonesia, Akar Sejarah, Himbauan dan Prospeknya, Gema Insani Press, Jakarta, 1996.

Daniel S. Lev, Hukum dan Politik di Indoensia Kesinambungan dan Perubahan, LP3ES, Jakarta : 1990.

Inu Kencana Syafii, Sistem Administrasi Negara Republik Indonesia (SANRI), Bumi Aksara, Jakarta, 2003.

Merdi Hajiji, Relasi Hukum dan Politik dalam Sistem Hukum Indonesia, Jurnal Rechts Vinding, Volume 2, Nomor 3, Desember 2013.

Peter de Cruz, Perbandingan Sistem Hukum Common Law, Civil Law and Socialist Law, Nusa Media, Bandung, 2010. 
Rikardo dkk, Pluralisme Hukum Sebuah Pendekatan Interdisiplin, Huma, Jakarta, 2005.

Sigit Somadiyono, Peran Kantor Wilayah Provinsi Jambi dalam Penyelesaian Sengketa Pertanahan melalui Mekanisme Mediasi, Wajah Hukum, Vol 1, No 1, Oktober 2017. Subekti, Pokok-Pokok Hukum Perdata, Jakarta: Intermasa, 1985.

Moh. Mahfud MD, Politik Hukum di Indonesia, Pustaka LP3ES Indonesia, Jakarta, 2001.

Zaka Firman Aditya \& Rizkisyabana Yulistyaputri, Romantisme Sistem Hukum di Indonesia : Kajian atas Kontribusi Hukum Adat dan Hukum Islam terhadap Pembangunan Hukum di Indonesia, Jurnal Rechts Vinding, Volume 8, Nomor 1, April 2019. 